\title{
SAMODZIELNOŚĆ FINANSOWA GMIN W KONTEKŚCIE REALIZACJI DOCHODÓW BUDŻETOWYCH
}

\author{
Anna Milewska \\ Katedra Finansów \\ Szkoła Główna Gospodarstwa Wiejskiego w Warszawie
}

\begin{abstract}
Abstrakt. Samorząd terytorialny w Polsce funkcjonuje jako niezależny podmiot sektora finansów publicznych. Wykonuje on bowiem zadania (przyjmujące najczęściej formę usług publicznych) na rzecz swoich mieszkańców we własnym imieniu i na własną odpowiedzialność. W tym celu zobowiązany jest do posiadania środków finansowych zabezpieczających realizację zarówno zadań własnych jak i zleconych z zakresu administracji publicznej. 0 ile w tym drugim przypadku, co do zasady, może liczyć na wsparcie w postaci dotacji celowych z budżetu centralnego, o tyle realizację zadań własnych powinien zabezpieczać samodzielnie. Oznacza to, iż samorządy mają możliwości (w aspekcie określonym aktami prawnymi) do samodzielności finansowej w zakresie organizacji i gromadzenia dochodów budżetowych.
\end{abstract}

Słowa kluczowe: samorząd, samodzielność, dochody budżetowe

\section{WSTĘP}

Za początek funkcjonowania samorządu terytorialnego w Polsce przyjmuje się rok 1990. W tym bowiem okresie w miejsce „gmin”, które do tego czasu, były w zasadzie wyłącznie jednostkami podziału terytorialnego, nadzorowanymi przez organy administracji centralnej, powołano jednostki samorządu terytorialnego. One również nosiły nazwę „gmin”, ale te nowo powstałe podmioty zostały wyposażone w osobowość prawną. Posiadają także własne mienie i organy stanowiące (rady gmin) pochodzące z wyborów. Kolejnym etapem działań zmierzających do demokratyzacji samorządów było uchwalenie przez Sejm w dniu 20 czerwca 2002. r. 
ustawy o bezpośrednim wyborze wójta, burmistrza czy też prezydenta miasta [Ustawa 2002 r.]. Tajne głosowanie dotyczące organu wykonawczego odbywa się powszechnych, równych i bezpośrednich wyborach.

Pierwszą ustawą, na mocy której gminy organizowały swoją gospodarkę finansową była ustawa z dnia 14 grudnia 1990 r. o dochodach gmin i zasadach ich subwencjonowania w latach 1991-1993 oraz o zmianie ustawy o samorządzie terytorialnym [Ustawa 1990 r.]. Nie była ona jednak w pełni precyzyjna, dlatego też w trzy lata później zweryfikowano jej zapisy i uchwalono ustawę o finansowaniu gmin. Dotyczyła ona regulacji źródeł pozyskiwania przez gminy dochodów oraz zasad finansowania deficytu budżetowego. W 1995 r. powołano również ustawę miejską, której treścią było określenie zasad przejmowania przez większe miasta wybranych zadań, wykonywanych wcześniej przez administrację państwową [Ustawa 1995 r.]. Priorytetem w przekazywaniu nowych i zwiększaniu zakresu istniejących już zadań publicznych była świadomość, iż problemy lokalne najszybciej i najefektywniej rozwiązywane przez organ administracyjny znajdujący się w zasięgu i pod kontrolą społeczności lokalnej. Myśl ta była również ideą przeprowadzonej w 1999 r. reformy administracji samorządowej. Na podstawie jej zapisów, obok najniższego szczebla samorządu - gminy, zaczęły funkcjonować dwie nowe jednostki samorządu terytorialnego: powiat i województwo. Część dużych miast, wykonujących wybrane zadania tzw. powiatowe jeszcze przed wejściem w życie tej ustawy, otrzymała możliwość utworzenia samodzielnych powiatów. Na tej podstawie powołano 65 powiatów noszących miano "grodzkich”, miast na prawach powiatu. Pozostałe zaś gminy zorganizowano w 308 powiatach tzw. „ziemskich”. Zakres obowiązków i praw nowych jednostek samorządu określały poszczególne ustawy, odnoszące się rozłącznie do gmin, powiatów i województw. W roku 2017 r. Polska dzieli się na 16 województw, 314 powiatów i 2478 gmin [Administracja 2017]:

- 302 miejskich w tym 66 miast na prawach powiatu,

- 621 miejsko-wiejskich,

- 1555 wiejskich.

Celem artykułu jest ukazanie zakresu samodzielności finansowej ze szczególnym uwzględnieniem jednostek gminnych. Wybór tego szczebla samorządu podyktowany był posiadaniem najszerszego katalogu dochodów własnych przez te podmioty. Specyfika dochodów własnych gmin zostanie zaprezentowana w dalszej części artykułu, jednakże w tym miejscu warto wskazać na fakt, iż w zakresie dochodów własnych mieszczą się przede wszystkim wpływy z podatków i opłat lokalnych. Wpływy budżetowe z tych tytułów mogą być kształtowane poprzez realizację władztwa podatkowego. Jego zakres a z nim związana także samodzielność będą miały bezpośrednie znacznie dla lokalnego budżetu. 
W artykule wykorzystano jakościowe metody badawcze, oparte w głównej mierze na obserwacji, analizie dokumentacji, tekstów aktów prawnych oraz pogłębionych studiów literatury przedmiotu. Posłużono się także metodą wnioskowania indukcyjnego i dedukcyjnego.

\section{PODSTAWY FORMALNOPRAWNE FINANSÓW SAMORZĄDOWYCH}

Najważniejszym aktem prawnym traktującym o finanse jednostek samorządu terytorialnego jest Konstytucja Rzeczpospolitej Polskiej z dnia 2 kwietnia 1997 r., która zagadnieniom samorządu dedykuje zapisy rozdziału VII [Konstytucja 1997 r.]. Wyodrębnione są w nim źródła dochodów, przy jednoczesnym określeniu ich gwarancji ustawowej. Dwukrotnie także podkreślona została zasada adekwatności dochodów do zadań i kompetencji (art. 167ust. 1 i 4). Jednakże najistotniejszym z punktu widzenia realizacji tychże dochodów, źródłem prawa regulującym problematykę dochodów jednostek samorządowych jest ustawa z dnia 13 listopada 2003 o dochodach jednostek samorządu terytorialnego [Ustawa 2003]. Ten akt prawny w sposób kompleksowy ujmuje problematykę dochodów gminnych. Określa źródła ich pochodzenia, zasady gromadzenia, jak również zasady ustalania oraz tryb przekazywania subwencji ogólnych i dotacji celowych.

Konieczność finansowania zadań przez gminę determinuje wyposażenie jej w odpowiednie środki finansowe. Ujęcie dochodów własnych, zapisane w art. 167 ust. 2 Konstytucji RP, definiuje dochody własne jako wszystkie pozyskiwane przez gminę dochody z wyłączeniem subwencji i dotacji. W związku z takim kryterium udziały gminy w podatkach stanowiących dochód budżetu państwa są również postrzegane jako dochody własne. Potwierdziły to także zapisy ustawy o dochodach jednostek samorządu terytorialnego. Jest to rozwiązanie racjonalne, ponieważ zarówno podatek dochodowy od osób fizycznych, jak i od osób prawnych wypracowywany jest przez te osoby z korzyścią dla gminy. Osoby fizyczne i prawne zamieszkujące na terenie danej gminy i wypracowujące określony dochód, który rozdysponowany jest między jednostki samorządu terytorialnego a budżet państwa, powodują „zatrzymanie” pewnej części dochodu na terenie gminy. Gminy dążą do osiągnięcia optymalnych dochodów przy akceptowanych obciążeniach podatkowych przez zameldowane w gminie osoby fizyczne oraz prawne i na tym bazują kreowanie lokalnej polityki podatkowej [Satoła 2014].

Dostrzega się także podział dochodów na te, których cechą charakterystyczną jest przymus pozyskania (podatki, opłaty, kary i grzywny) oraz dobrowolne (zapisy, spadki, darowizny). Podział dochodów budżetów gmin na podatkowe i niepodatkowe to ujęcie również dość często spotykane w literaturze. Dochody 
podatkowe zawierają w sobie podatki lokalne, dochody z udziałów w podatkach centralnych. Wpływami budżetowymi zawartymi w tym katalogu mogą być także dochody z samoopodatkowania się mieszkańców. na cele publiczne mieszczące się w zakresie zadań i kompetencji organów gmin. Wynik referendum gminnego w sprawie samoopodatkowania się mieszkańców na cele publiczne jest rozstrzygający, jeżeli za samoopodatkowaniem oddano co najmniej $2 / 3$ ważnych głosów [Ustawa 2000]. W odniesieniu do dochodów niepodatkowych zaliczane są do tej grupy subwencje ogólne, dotacje celowe, dochody z majątku, opłaty, zapisy, spadki darowizny, grzywny i kary. W aspekcie szerokiego katalog dochodów budżetowych gmin należy także wziąć pod uwagę stabilność i pewność źródeł finansowania. One bowiem znacząco determinują zakres i poziom usług publicznych świadczonych przez jednostki samorządu terytorialnego oraz zadań obligatoryjnych i fakultatywnych, wynikających z odpowiednich unormowań prawnych [Satoła 2015].

\section{SAMOFINANSOWANIE A SAMODZIELNOŚĆ FINANSOWA GMIN - WYNIKI ANALIZY}

Rozważając zagadnienia autonomii finansowej jednostek samorządu terytorialnego, należy wprowadzić rozróżnienie pomiędzy samofinansowaniem a samodzielnością finansową tych jednostek [Piotrowska-Marczak 1997]. Samofinansowanie oznacza bowiem, gospodarkę finansową prowadzoną w oparciu o dochody własne, które mogą być pozyskiwane z wielu źródeł i na odmiennych zasadach. Natomiast samodzielność finansowa nie wymaga konieczności tworzenia dochodów własnych. Może być ona wyrażona poprzez swobodę dysponowania dochodami, nawet $\mathrm{w}$ przypadku dochodów uzyskiwanych w postaci transferów z budżetu państwa (subwencja ogólna czy dotacja celowa na dofinansowanie zadań własnych). Zaznaczyć należy, że samodzielność finansowa JST jest szerszym pojęciem, uwzględniają-cym węższe pojęcie, jakim jest samodzielność dochodowa [Czarny 2015].

Subwencja ogólna stanowiła i stanowi istotne źródło dochodów budżetowych. Ponad 20 lat temu (w 1996 r.) odnotowano silne wewnętrzne zróżnicowanie budżetów gmin wiejskich w Polsce. Szczegółowy układ wsparcia budżetów przez transfer z budżetu państwa jakim jest subwencja ogólna zobrazowano na rysunku 1 . Wsparcie subwencyjne jest dla samorządów niezwykle ważną pozycją budżetową. Co prawda są to tzw. uzależniające źródła dochodów, jednakże gmina wpływami z subwencji może swobodnie dysponować. Wyjątek stanowić może część oświatowa subwencji ogólnej, która nosi znamiona dotacji celowej. Jest kalkulowana w oparciu o dane dotyczące oświaty (np. liczby uczniów szkół 


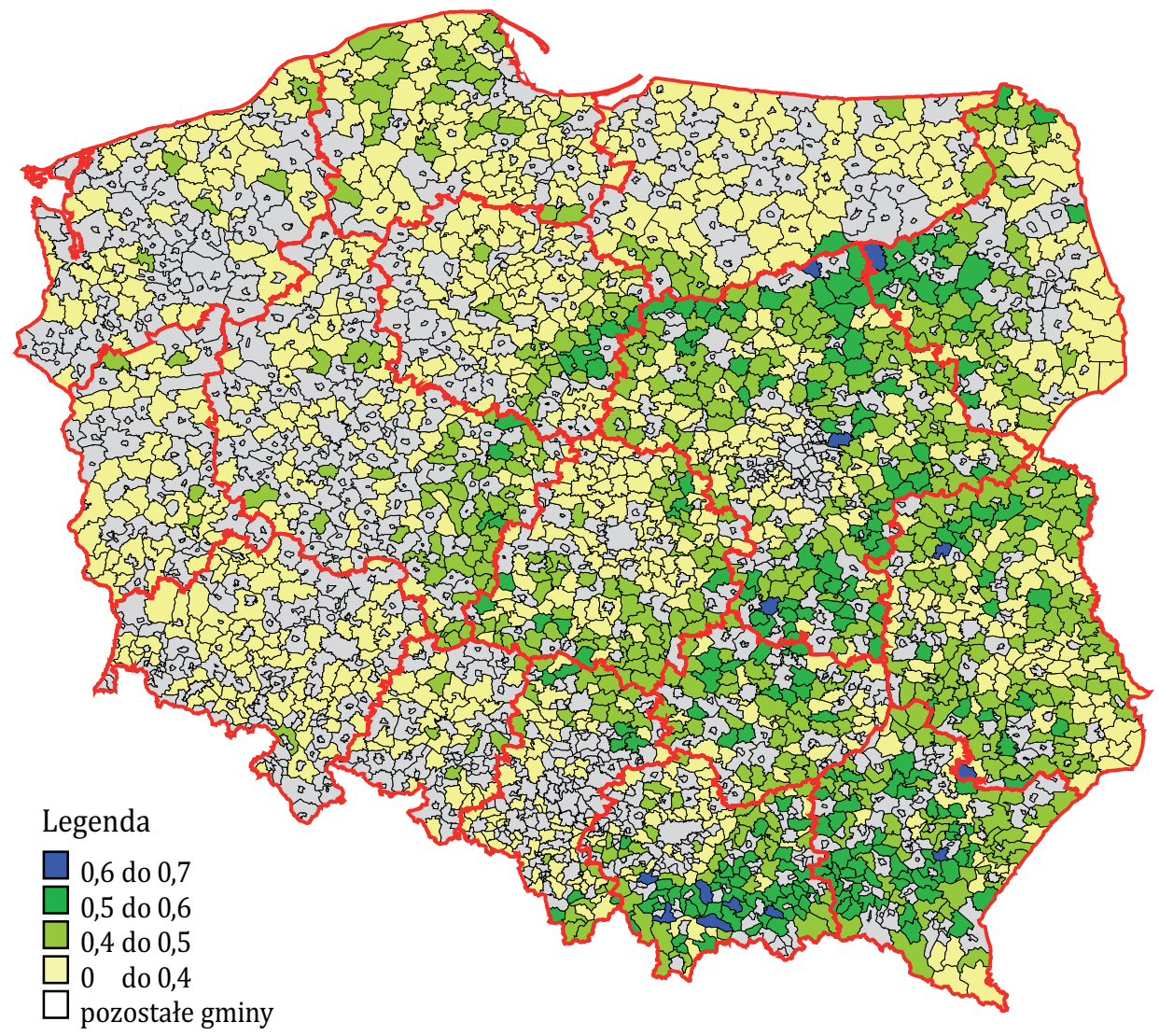

RYSUNEK 1. Przestrzenne zróżnicowanie wysokości udziału subwencji w dochodach ogółem gmin wiejskich w Polsce w roku 1996

Źródło: opracowanie własne na podstawie danych BDL.

podstawowych, liczby uczniów ogólnokształcących szkół muzycznych I stopnia, uczestników kwalifikacyjnych kursów zawodowych itp.) i wydatkowana jest na cele związane z wykonywaniem zadań oświatowych.

W odniesieniu do dotacji celowych, mogą być one przekazywane z budżetu państwa do innego podmiotu należącego do sektora finansów publicznych w tym także do samorządu terytorialnego. Samorząd, który otrzyma dotację określoną jako „celową" jest zobowiązany wydatkować ją na wskazany cel i w ramach określonej kwoty. Kwota niewydatkowana lub wydatkowana niezgodnie z wcześniejszym przeznaczeniem podlega zwrotowi do budżetu państwa, a opóźnienia w jej zwrocie zagrożone są odsetkami za zwłokę. Historyczne przestrzenne zróżnicowanie udziału dotacji celowych w budżetach gmin wiejskich w Polsce zamieszczono na rysunku 2. 


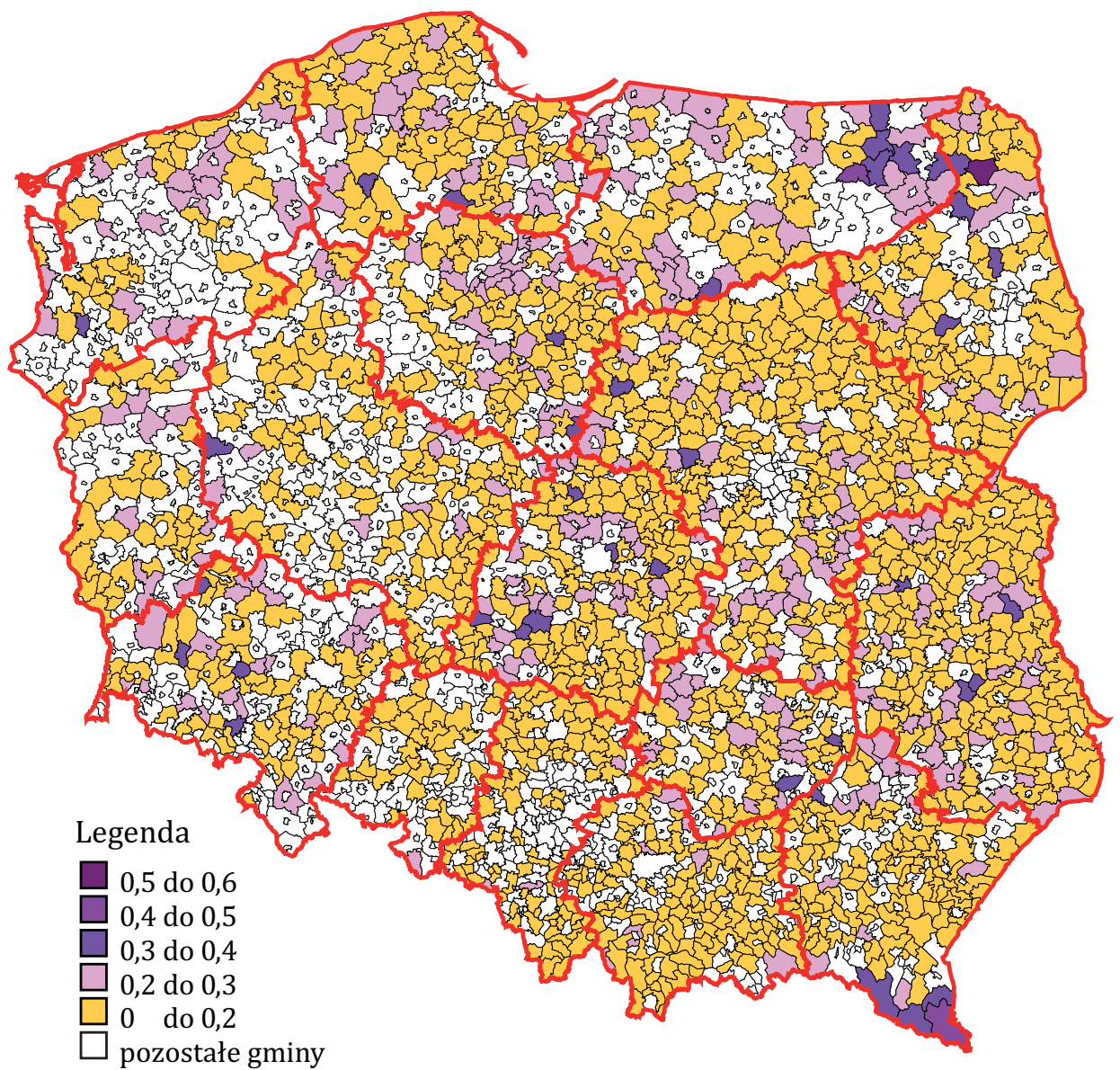

RYSUNEK 2. Przestrzenne zróżnicowanie wysokości udziału dotacji celowych w dochodach ogółem gmin wiejskich w Polsce w roku 1996

Źródło: opracowanie własne na podstawie danych BDL.

W 2016 r. w strukturze dochodów gmin ogółem najwyższy udział, bo 44,3\%, miały dochody własne, dotacje ogółem stanowiły 29,8\%, natomiast subwencja ogólna 25,9\%. W gminach wiejskich największa kategorią były dochody własne $(37,8 \%)$, jednak udział ten był dużo niższy niż w innych typach gmin. Dotacje ogółem i subwencja ogólna stanowiły kolejno 31,5\% i 30,7\% dochodów ogółem gmin wiejskich [GUS 2017].

W ujęciu modelowym dochody samorządu terytorialnego opierają się na podatkach od nieruchomości, nie tylko wydajnych fiskalnie, ale co ważne niewrażliwych na cykle gospodarcze oraz na subwencjach o charakterze ogólnym, w przy- 
padku których samorząd terytorialny ma samodzielność wydatkową. Duży zakres opłat za usługi umożliwia pewne zwiększenie wpływów z tego tytułu. Zdecentralizowane systemy finansów publicznych charakteryzują się również szerszym dostępem jednostek komunalnych do rynku finansowego i źródeł zwrotnych, oraz bezzwrotnych z funduszy parabudżetowych [Guziejewska 2008].

Istotne znaczenie $\mathrm{w}$ tym aspekcie ma przede wszystkim swoboda decyzyjna dotycząca spraw podatkowych, składająca się na tzw. lokalne władztwo podatkowe. Przez to pojęcie należy rozumieć zagwarantowaną prawnie swobodę kształtowania przez władze lokalne wielkości i struktury podatków oraz opłat lokalnych jako kluczowej kategorii dochodów własnych. Ważna płaszczyzna wspomnianej swobody dotyczy również możliwości kształtowania dochodów uzyskiwanych przez JST z tytułu posiadanych praw majątkowych - zakres samodzielności dochodowej w tym kontekście jest ściśle powiązany z wielkością i wartością mienia komunalnego. [Poniatowicz, 2015]. Dochody własne decydują o stopniu samodzielności finansowej gmin, a ich wzrost lub spadek ma bezpośredni wpływ na planowanie i realizację działalności inwestycyjnej [Brzozowska, Kogut - Jaworska, 2016].

Pod pojęciem dochodów własnych gmin rozumie się często „dochody płynące z własnej działalności organów lokalnych i jednostek im podporządkowanych oraz przyznawane budżetom lokalnym z dochodów z podatków i opłat" [Gajl 1986, Ustawa 1991]. Dochody własne definiowane są również jako „związane z budżetami lokalnymi w sposób trwały, bez żadnych ograniczeń ze strony państwa i bez jego udziału w części wpływów pochodzących z poszczególnych źródeł oddanych we władanie związków samorządowych" [Chojna-Duch, Kornberger-Sokołowska 1998].

Do dochodów własnych gminy zaliczono, jak wspomniano wcześniej, podatki i opłaty lokalne, dochody z majątku gminy oraz inne, m.in. spadki, zapisy, darowizny. Te trzy ostatnie charakteryzuje brak cykliczności a wręcz zwykle jednorazowość lecz decyzją ustawodawcy zostały zakwalifikowane jako dochody a nie jako przychody gminne.

Podatki i opłaty definiowane jako lokalne „są to podatki i opłaty niekiedy diametralnie różniące się od siebie pod względem ekonomicznym i konstrukcyjnym”, „nie mające w większości specjalnych cech, które by ich lokalny charakter potwierdzały. Określenie rodzajowe podatków i uznawanie ich za lokalne ma w większości charakter umowny" [Gail 1993]. Ze względu na przytoczone rozważania pojęcie podatków i opłat lokalnych można traktować w węższym i szerszym zakresie. Zakres węższy uznaje za lokalne wyłącznie te daniny, które stanowią przejaw władztwa podatkowego gminy. W szerszym zakresie za lokalne rozumie się te wszystkie podatki (np. udział gminy w podatku dochodowym od osób fizycznych i prawnych) i opłaty, które stale i cyklicznie, w oparciu o obowiązujące przepisy prawa, zasilają lokalne budżety. 
Podatki i opłaty lokalne (samorządowe) należą do grupy dochodów własnych gmin. Ich udział (w relacji do dochodów ogółem) w strukturze dochodów budżetów gminnych jest zróżnicowany. Jednakże przez wzgląd na to, iż to władze lokalne mają wpływ na kształtowanie ich wielkości i struktury, uważa się je za podstawowe dochody budżetów gmin w Polsce. Podatkami zaliczonymi do grupy podatków lokalnych sensu stricte są:

- podatek od nieruchomości,

- podatek od środków transportowych.

Pozostałymi podatkami samorządowymi są: podatek rolny, podatek leśny, podatek od spadków i darowizn, podatek opłacany w formie karty podatkowej, podatek od czynności cywilno-prawnych. Natomiast do opłat o charakterze lokalnym należą:

- opłata targowa,

- opłata miejscowa,

- uzdrowiskowa,

- reklamowa,

- od posiadania psów.

Pozostałe opłaty wymierzane są na podstawie odrębnych ustaw, np. opłata skarbowa czy opłata adiacencka.

Udziały gmin w podatkach dotyczą tych w podatku dochodowym od osób fizycznych i w podatku dochodowym od osób prawnych. Należy podkreślić, że gminy dysponują władztwem podatkowym jedynie w zakresie tych podatków, które są pobierane przez samorządowe organy podatkowe. Pozostałe podatki pobierane są przez organy skarbowe [Filipak 2015]. Kompetencje gmin w zakresie kształtowania elementów konstrukcji podatków nie są jednak znaczne. Władze lokalne nie mogą podnosić stawek podatkowych określonych w przepisach prawnych, a jedynie je obniżać i to też nie we wszystkich przypadkach. Władze lokalne w Polsce wykorzystują zatem przyznane im ustawowo możliwości oddziaływania na rozwój gospodarki gminy głównie poprzez określania wysokości stawek podatków lokalnych. Podatki te pełnią więc funkcję stymulacyjną. Wynika z tego, iż organy gminy prowadzą własną politykę podatkową. Tym samym wykorzystują swoje uprawnienia w celu ingerowania w poziom rozwoju gospodarczego na podległym im terytorium.

\section{PODSUMOWANIE}

Jednostki samorządu gminnego realizują zadania publiczne (własne i zlecone) gromadząc środki finansowe oraz pokrywając wydatki z nimi związane. W katalogu dochodów, obok subwencji ogólnej i dotacji celowych przekazywanych z budżetu państwa, występują przede wszystkim dochody własne. Gminy uprawnione 
są do „posługiwania się” władztwem podatkowym, które umożliwia im działania i ingerencję w zakres planowanej bądź prowadzonej polityki podatkowej. Jednostki te mają pełną swobodę decyzyjną i mogą określić stawki dla każdego rodzaju danin lokalnych. Warunkiem tak pojmowanej samodzielności finansowej jest jednak ograniczenie, iż stawki podatków i opłat lokalnych zawarte w uchwałach nie przekroczą maksymalnych stawek podatkowych ogłaszanych corocznie przez ministra właściwego ds. finansów publicznych. Stosowanie władztwa podatkowego to jednak także działanie obarczone ryzykiem. Zjawisko to może mieć miejsce w sytuacji planowanych, szybkich do uzyskania efektów, w zbyt krótkim okresie (np. 2 lat budżetowych). Jednakże, konsekwentna i spójna ze strategią rozwoju gminy polityka podatkowa przynosi zamierzone rezultaty.

\section{Spis literatury}

BRZOZOWSKA K., KOGUT - JAWORSKA M. 2016: Władztwo podatkowe w ocenie samodzielności dochodowej gmin w Polsce, ANNLES UNIVERSITATIS MARIAE CURIE - SKŁODOWSKA, VOL. L, 1 SECTIO H, Lublin, s. 327-337.

CHOJNA-DUCH E. 1998: KORNBERGER-SOKOŁOWSKA E., Dochody gmin z podatków i opłat, Wyd. Twigger „Ecostar”, Warszawa.

CZARNY A. 2015: Samodzielność dochodowa jednostek samorządu terytorialnego na przykładzie wybranych miast wojewódzkich, FOLIA POMERANAE UNIVERSITATIS TECHNOLOGIAE STETINENSIS, Folia Pomer. Univ. Technol. Stetin., Oeconomica 2015, 317(78)1, s. 37-46.

FILIPIAK B. Z. 2015: Polityka podatkowa czy realizacja władztwa podatkowego, Zeszyty Naukowe Uniwersytetu Szczecińskiego nr 864, Finanse, Rynki Finansowe, Ubezpieczenia nr 76, t. 1, s. 221-230.

GAJL N. 1996: Finanse i gospodarka finansowa, Państwowe Wydawnictwo Naukowe, Warszawa.

GAJL N. 1993: Finanse i gospodarka lokalna na świecie, Wyd. PWE, Warszawa 1993, s. 129.

Gospodarka finansowa jednostek samorządu terytorialnego 2016, Główny Urząd Statystyczny, Warszawa 2017.

GUZIEJEWSKA B. 2008: Efektywność finansów samorządu terytorialnego, Gospodarka Narodowa $\mathrm{Nr}$ 5-6, s. 71-89.

Konstytucja Rzeczypospolitej Polskiej z dnia 2 kwietnia 1997 r. (Dz.U. 1997 nr 78 poz. 4830).

PIOTROWSKA-MARCZAK K. 1997: Finanse lokalne w Polsce, Wydawnictwo Naukowe PWN, Warszawa.

PONIATOWICZ M. 2015: Determinanty autonomii dochodowej samorządu terytorialnego w Polsce, Prace Naukowe Uniwersytetu Ekonomicznego we Wrocławiu nr 404, Wrocław, s. 11-30. 
SATOŁA Ł. 2014: Wpływ polityki podatkowej gmin na poziom przedsiębiorczości (na przykładzie podatku od nieruchomości), Nierówności Społeczne a Wzrost Gospodarczy, nr 40 (4), s. 238-247.

SATOŁA Ł. 2015: Kondycja finansowa gmin $w$ warunkach zmiennej koniunktury gospodarczej, Journal of Agribusiness and Rural Development, 1(35), s. 115-123.

Ustawa z dnia 8 marca 1990 r. o samorządzie terytorialnym (Dz.U. z 1996 r. Nr 13 poz. 74, Nr 58 poz. 261, Nr 106 poz. 496 i Nr 132 poz. 622; z 1997 r. Nr 9, poz. 43, Nr 106 poz. 679, Nr 107 poz. 686, Nr 113, poz.734 i Nr 123, poz. 775; z 1998r. Nr 155, poz. 1014) z dniem 1 stycznia 1999 r. otrzymała tytuł w brzmieniu: „o samorządzie gminnym” (Dz.U. z 2001 r., Nr 142, poz. 1591).

Ustawa z dnia 12 stycznia 1991 r. o podatkach i opłatach lokalnych, (Dz.U. nr 9, poz. 31 z późn. zmianami).

Ustawa z dnia 24 listopada 1995 r. o zmianie zakresu działania niektórych miast oraz o miejskich strefach usług publicznych (Dz.U. $1997 \mathrm{Nr} 36$ poz. 224).

Ustawa z dnia 15 września 2000 r, o referendum lokalnym (Dz. U. $2000 \mathrm{Nr} 88$ poz. 985).

Ustawa z dnia 20 czerwca 2002 r. o bezpośrednim wyborze wójta, burmistrza i prezydenta miasta (Dz.U. $2002 \mathrm{nr} 113$ poz. 984).

Ustawa z dnia 13 listopada 2003 o dochodach jednostek samorządu terytorialnego (Dz. U. 2003 nr 203 poz. 1966).

https://administracja.mac.gov.pl/adm/baza-jst/843,Samorzad-terytorialny-w-Polsce. html (dostęp z dnia 22.10.2017).

\title{
FINANCIAL AUTONOMY OF COMMUNES IN THE CONTEXT OF REALIZATION OF BUDGET REVENUES
}

\begin{abstract}
Local government in Poland functions as an independent entity in the public finance sector. It performs tasks (most often taking the form of public services) for its residents on its own responsibility. For this purpose, this unit is obliged to organize financial guarantee the implementation of both (own and commissioned tasks in the field of public administration). While in the second case, as a rule, can count on support in the form of targeted subsidies from the central budget, local government should secure own tasks independently. This means that local governments have the possibility (in the aspect specified by legal acts) for financial independence in terms of organizing and collecting budget revenues.
\end{abstract}

Key word: local government, financial autonomy, budget's incomes 